\title{
AN INVESTIGATION OF THAI STUDENTS' ENGLISH LANGUAGE LEARNING STRATEGIES
}

\author{
Agus Trioni Nawa \\ Institut Agama Islam Negeri Metro \\ E-mail: agustrioninawa@metrouniv.ac.id
}

\begin{abstract}
The purpose of this study was to investigate the English language learning strategies implemented by Thai students with the consideration of gender variable. The study employed a descriptive quantitative research design which involved administering questionnaires of rating scale using Oxford, (1990) Strategy Inventory for Language Learning (SILL) to investigate the most frequent language learning strategies from 38 Thai students (15 males and 23 females) of Wahid Hasyim University of Semarang. This study revealed that females showed more strategic (3.34) in learning English than males (2.823). Generally, females showed more frequent use social strategies and males showed more frequent use affective strategies.
\end{abstract}

Keywords: Thai Students, English Language Learning Strategies

\section{INTRODUCTION}

There are many factors affect in acquiring language, one of them is teaching strategy. An appropriate language teaching strategy choice is going to determine the quality of students' language acquisition. However, implementing the appropriate language teaching strategy was not an easy one, because, at first, the teacher must know what kind of language learning strategies probably used by students.

The concept of strategy is a somewhat fuzzy one. It consisted of mental or behavioral activity related to some specific stage in the overall process of language acquisition or language use (Rod Ellis, 1999). It is also widely phenomenon in bilingual and multilingual communities. The language learning strategy choices are affected by several factors; social, behavioral and situational.

Every student has different language learning strategies in improving his/ her language proficiency, including Thai students. This condition is also happening on Thai students at Wahid Hasyim University.
Rebecca L. Oxford, (1990) simply classifies language learning strategy into six categories. Those are memory strategy, cognitive strategy, compensation strategy, metacognitive strategy, affective stategy and social strategy.

J. O'Malley \& A. Chamot, (1990) have anchored their own work, with some success, in a cognitive theory of information processing. As a result, the nature of the strategies that have been identified varies enormously. However, Rod Ellis, (1999) states that "there is no agreement about what constitutes a learning strategy". There is no widely accepted theoretical basis for identifying and describing strategies.

A lot of the research has been based on the assumption that there are "good" learning strategies. But this is questionable. The beneficial effect of strategies may be relative to the kinds of task they are deployed in. For example, some strategies may work in task aimed at the development of linguistics competence and other in task with more communicative objectives (Rod Ellis, 1999). Effective strategy may consist of the 
flexible deployment of the right strategies in the right task, but little is currently known about this. It is also possible that different strategies are important for classroom and naturalistic language learning and for children as opposed to adult.

Therewereseveralstudiesinvestigated languagelearningstrategies.Pathomchaiwat, (2013) found that the students most intended to guessing intelligently, or compensation strategy. Moreover, Suwanarak, (2015) investigated Thai adult learners revealed that the learners reported overall preference for the use of social strategies by asking whether or not they often practicing the pronunciation to themselves, they explain that it was just in case they were sure of the correct pronunciation. However, Sri Wahyuni \& Muhammad Ilyas, (2016) studied Thai students' English language learning strategies in Indonesia revealed the participant using social strategy most frequently than other strategies. It was happening because of the students were unable to understand classroom lecturers in English. The differences of students' language learning strategy choice might be affected by difference of students' characters.

Comprehending students' characters is not as easy as seem like, especially Thai students who come from different social environment. According to problem discussed, this study was conducted to facilitating teachers to comprehend Thai students in using language learning strategies to learn English as a foreign language in foreign country and foreign environment. In addition, by providing information for the teachers about Thai students' English language learning strategies, hopefully [s] he also able to determine what appropriate teaching strategies to. To sum up, the students' success in acquiring language are supported by several aspects, those are learning strategies and teachers' guidance.

\section{THEORETICAL REVIEW}

Differences in individual student characteristics partially explain variation in English language learning outcomes, social context factors are also important (A. Charhil, C. Suarez-Orozco, \& M. Paez, 2008).

In behaviorist theory, learning is process of imitation, practice, reinforcement, and habit formation. Classroom activities in behaviorism theory of language learning, as presented on the audio-lingual method, emphasize mimicry and memorization, and students learned dialogues and sentence pattern by heart (P.M. Lightbrown \& S. Nina, 2006). D. Hewitt, (2008) stated that learning is a complex concept and activity. Furthermore, he informs that most teachers and pupils would recognize the importance of the social and emotional elements of learning, in addition to cognitive aspects of learning, thinking and problem solving.

Since language development was viewed as the formation of habits. It was assumed that a person learning a second or foreign language would start off with the habit formed in the first language and that these habits would interface with the new ones needed for the second language. In the other word, learning a second or foreign language was considered to have the same process as learning the first language.

There is a perspective that every child born is equipped with language acquisition device (LAD) gives a different perspective that innate knowledge of the principles of universal grammar permits children to acquire the language for their first language and even for their second or foreign language (P.M. Lightbrown \& S. Nina, 2006).

There are various forms of informal learning:

a. Implicit learning, where learning is not undertaken in any conscious way, and there is no conscious knowledge of what has been learned. 
b. Reactive learning, which is seen as being near spontaneous in its development. The knowledge from this type of learning is only marginally open to conscious interrogation.

c. Deliberative learning, which takes place in a planned context, and is the most open of informal learning to conscious reflection.

\section{Language Learning Strategy}

In acquiring language, human may be automatically grabbing the language they are facing every day in their lives. It happens because human has ability to imitate others. However, the ability of someone in grabbing language is based on the society they are involved. It means that, although, language can be acquired automatically but it must be learnt to be understood well by employing language learning strategy.

Learning is an activity of obtaining knowledge, while strategy is a detailed plan for achieving success in situations such as war, politics, business, industry or sport, or the skill of planning for such situations. Learning strategy is specific actions taken by the learner to make learning easier, faster, more enjoyable, more self-directed, more effective and more transferable to new situations (Rebecca L. Oxford, 1990). According to this explanation, it could be understood that the language learning strategies are specific manner and plan used by learners to learn for acquiring language (Ernesto Macaro, 2001).

Rod Ellis, (1999) has been characterizing how the term 'strategies' has been used in the studies to be considered:

1. Strategies refer to both general approaches and specific actions or technique used to learn an L2.

2. Strategies are problem-oriented; the learner deploys a strategy to overcome some particular learning problem.

3. Learners are generally aware of the strategies they use and can identify what they consist of if they are asked to pay attention to what they are doing/ thinking.

4. Strategies involved linguistic behavior (such as requesting the name of an object) and non-linguistic (such as pointing at an object so as to be told its name).

5. Linguistic strategies can be performed in the L1 and in the L2.

6. Some strategies are behavioral while others are mental. Thus some strategies are directly observable, while others are not.

7. In the main, strategies contribute indirectly to learning by providing learners with data about the L2 which they can then process. However, some strategies may also contribute directly (for example, memorization strategies directed at specific lexical items or grammatical rules).

Strategy use varies considerably as a result of both the kind of task the learner is engaged in and individual learners' preferences.

\section{The Kind of Language Learning Strategy}

Language learning strategies are classified into two major strategy classes: direct and indirect strategy (Rebecca L. Oxford, 1990). Direct strategy deals with mastering new language composes of remembering, retrieving, understanding and producing the language. Moreover, indirect strategy composes of coordinating learning process, regulating emotions and learning with others. In short, direct strategy consists of memory strategy, cognitive strategy and compensation strategy. Moreover, indirect strategy consists of metacognitive, affective and social strategy.

Memory strategies are the basic strategy of human learning, it often used by 
elementary level form thousand years ago. Memory strategy relates to remembering new language. This strategy employs learners to visualizing new words or phrases into images to help them remember new language. It falls into four sets:

1. Creating mental linkages: a) grouping; b) associating/ elaborating; c) placing new words into a context.

2. Applying images and sound: a) using imagery; 2) semantic mapping; c) using keywords; d) representing sound in memory.

3. Reviewing well: structured reviewing

4. Employing action: 1) using physical response or sensation; 2) using mechanical techniques.

The next direct strategy is cognitive strategies. This strategy helps learners take advantage of variety of learning resources by practicing, analyzing and even taking notes. This strategy falls into four following sets:

1. Practicing: a) repeating; b) formally practicing with sound and writing systems; c) recognizing and using formulas and patterns; d) recombining; e) practicing naturalistically.

2. Receiving and sending messages: a) getting idea quickly; b) using resources for receiving and sending messages.

3. Analyzing and reasoning: reasoning deductively; b) analyzing expressions; c) analyzing contrastively (across language); d) translating; e) transferring.

4. Creating structure for input and output: a) taking notes; b) summarizing; c) highlighting.

The last kind of direct strategy is compensation strategies. Many learners when faced with unknown expressions, they may employ their mind by guessing intelligently. Even, when learners confronted with unknown expressions supposed to say, they may switch those expressions to their mother tongue. These actions relate to compensation strategy.

The compensation strategy falls into two sets:

1. Guessing intelligently: a) using linguistic clues; b) using other clues.

2. Overcoming limitation in speaking and writing: a) switching to the mother tongue; b) getting help; c) using mine or gesture; d) avoiding communication partially or totally; e) selecting the topic; f) adjusting or approximating the message; g) coining words.

The direct language learning strategy performs as a director of a play. It has responsible to checking, correcting, coaching and ensuring that the performance works cooperatively with other actors. In the other word, the direct language learning strategy deals with the learners' cognition.

Furthermore, the second major class of language learning strategies is indirect strategy. Indirect strategy performs as performers of a play. This strategy relates to the learners' social environment. It is divided into metacognitive, affective and social strategy.

First, metacognitive strategies allow the learners to control their own cognition, that is, to coordinate the learning process, arranging, planning and evaluating. It includes three strategy sets:

1. Centering your learning: a) overviewing and linking with already known material; b) paying attention; c) delaying speech production to focus on listening.

2. Arranging and planning your listening: a) finding out about language learning; b) organizing; c) setting goal and objectives; d) identifying the purpose of language task; e) planning for a language task; f) seeking practice opportunities.

3. Evaluating your learning: a) selfmonitoring; b) self-evaluating. 
Second, affective strategies. These strategies help to regulate emotions, attitudes, motivations, and values. The sets of affective strategies are:

1. Lowering your anxiety: a) using relaxation; b) using music; c) using laughter.

2. Encouraging yourself: a) making positive statements; b) taking risk wisely; c) rewarding yourself.

3. Taking your emotion temperature: a) listening to your body; b) using a checklist; c) writing a language learning diary; d) discussing your feeling with someone else.

The last, social strategies. These strategies deal with learners' cooperation with other learners or even teachers or proficient users of the new language. They fall into three sets of strategies that can be remembered by using acronym ACE (Asking questions, Cooperating with others, and Empathizing with others).

1. Asking questions: a) asking for clarification or verification; b) asking for correction.

2. Cooperating with others: a) cooperating with peers; b) cooperating with proficient users of the new language.

3. Empathizing with others: a) developing cultural understanding; b) becoming aware of others' thoughts and feelings.

To sum up, there are two classes of language learning strategies (direct and indirect). Those two strategies then subdivided into a total of nineteen strategy sets. In learning, the direct strategy performs as a director, while indirect strategy plays role as an actor or performer. $\backslash$

\section{RESEARCH METHOD}

This study employed descriptive researchdesignwhichinvolvedadministering Strategy Inventory of Language Learning (SILL) by Oxford, (1990) to answer what most frequent of English language learning strategies employed by 38 Thai students of Wahid Hasyim University of Semarang. This questionnaire involved of six categories of language learning strategies including memory strategies, cognitive strategies, compensation strategies, metacognitive strategies, affective strategies and social strategies.

Descriptive static analysis was carried out to answer the research question. Descriptive research is a type of quantitative research that involves making careful description of education phenomena, and this kind of research is used to study phenomena as they exist at one point in time (Gall, \& Borg, 2003).

Before administering the questionnaires, the researcher did trial test to figure out the validity and reliability. Afterward, the SPSS 20 was employed to compute means and standard deviation in order to measure the frequency of English language learning strategy used by Thai students. The English language learning strategy frequency were classified into 5 levels: 1) never or almost never true of me; 2) usually not true of me; 3) somewhat true of me; 4) usually true of me; 5) always or almost always true of me.

Table 1. The Students' Averages of Language Learning Strategies Implementation

\begin{tabular}{cc}
\hline Score & Category \\
\hline $4.5-5.0$ & High \\
$3.5-4.4$ & \\
$2.5-3.4$ & Medium \\
$1.5-2.4$ & Low \\
$1.0-1.4$ & \\
\hline
\end{tabular}

\section{FINDING AND DISCUSSION}

Means and standard deviations were computed to measure the use of six strategy categories and the overall strategy instrument in each different gender. 
According to table 2, the male Thai students were preferred to implement affective, metacognitive and social strategies, while, the compensation, memory and cognitive strategies were found to be the least.

Meanwhile, the female Thai students were investigated to implement social, compensation, and affective strategies in preference. However, metacognitive, cognitive and memory strategies were found to be the least used by female students.

In summary, female Thai students were more strategic than males in learning English (male $[\mathrm{M}=2.823$, Std. Dev. = 0.851], female $[\mathrm{M}=3.34$, Std. Dev. $=$ $0.627]$ ). This result obviously declared that females Thai students are more strategic in learning English Than males.

\begin{tabular}{|c|c|c|c|c|}
\hline \multirow{4}{*}{ Strategy } & \multicolumn{4}{|c|}{ Gender } \\
\hline & \multirow{2}{*}{\multicolumn{2}{|c|}{$\begin{array}{l}\text { Male } \\
\text { (N 13) }\end{array}$}} & \multirow{2}{*}{\multicolumn{2}{|c|}{$\begin{array}{r}\text { Female } \\
\text { (N 25) }\end{array}$}} \\
\hline & & & & \\
\hline & M & SD & $\mathrm{M}$ & $\mathrm{SD}$ \\
\hline Memory & 2.519 & 1.033 & 3.276 & 0.641 \\
\hline Cognitive & 2.469 & 0.805 & 3.28 & 0.617 \\
\hline Compensation & 2.892 & 0.895 & 3.492 & 0.734 \\
\hline Metacog & 3.023 & 0.87 & 3.292 & 0.682 \\
\hline Affective & 3.076 & 1.084 & 3.328 & 0.78 \\
\hline Social & 2.907 & 0.918 & 3.50 & 0.739 \\
\hline Overall & 2.823 & 0.851 & 3.34 & 0.627 \\
\hline
\end{tabular}

Furthermore, Table 3 demonstrates the frequency of six categories of the language learning strategies use. There were differences between this frequencybased strategy ranking implemented by males and females learners. It informs that males were more affective, while females were more social. This result indicated that male learners seemed pay more attention to the adjustment and control their moods. Moreover, female learners significantly seemed more communicative in learning by cooperating with other learners, asking questions to the proficient English user and asking clarification and verification.

Table 3 The Frequency of Strategies Across Difference of Gender

\begin{tabular}{ccc}
\hline Rank & Male & Female \\
\hline $\mathbf{1}^{\text {st }}$ & Affective & Social \\
$\mathbf{2}^{\text {nd }}$ & Metacognitive & Compensation \\
$\mathbf{3}^{\text {rd }}$ & Social & Affective \\
$\mathbf{4}^{\text {th }}$ & Compensation & Metacognitive \\
$\mathbf{5}^{\text {th }}$ & Memory & Cognitive \\
$\mathbf{6}^{\text {th }}$ & Cognitive & Memory \\
\hline
\end{tabular}

Affective Strategies and Teachers' Role

Affective strategies deal with selfcontrolling, especially in lowering anxiety, encouraging self and taking emotional temperature. Male Thai students were reported applying these strategies in high frequency than other strategies. As they'd reported that "I try to relax whenever I feel afraid of using English" and "I encourage myself to speak English even when I afraid of making a mistake". In lowering anxiety, they applied to listening music few minutes before and after study English, or even when learning process was running. And, sometimes they took deep breathing when facing with English task. Those behaviors, unconsciously, reflected discomfort feeling in learning English.

Listening music in classroom or using other progressive relaxations such as deep breathing or meditation are better way to lowering anxiety. It helps students to relax and ready to study in classroom or just about anywhere else.

Beside it, using music can help students to enhance second/foreign language acquisition. There are so many researches study the influence of music to language acquisition (McMullen \& Saffran, [2004]; Niño, [2010]; Srisupha, [2013]; Lee \& Lin, [2015]; Kuśnierek, [2016]). Horn, (2007) noted that language development and music development have many similarities. Music significantly change in such a stable characteristic as development 
of vocabulary (Yarikova, 2009). Teachers can also both lowering students' anxiety and improving their language acquisition by playing musing in classroom. A few minutes of relaxation in the classroom or at home using progressive relaxation, such as listening music, breathing deeply, will help learners accomplish their learning tasks more peacefully and more efficiently (Oxford, 1990).

Teaching English as foreign language for the students from foreign country is not an easy one. As noted that when students do not exactly know what ideas supposed to say, they cannot transfer or switch them (ideas) into their mother tongue (vernacular). This condition significantly improves the students' anxiety in classroom language learning. It becomes the realistic reasons, why do male Thai students tend to implement affective strategy.

According to this condition, the English language teachers are expected to be aware and able to adjust their teaching strategies to the students' condition by lowering students' anxiety, encouraging them, and teaching them to taking their emotional temperature. Five or ten minutes of shooting music can calm learners and put them in a more positive mood for learning (Oxford, 1990). Bringing small tools of sound system, and asking students to play their favorite song, or asking volunteer to sing a song in front of the class or even playing comedy are better way before starting language learning process.

The other ways of lowering students' anxieties are teaching them to be brave in taking risk wisely. Speaking English fluently is an expectation. However, it needs process and practice. By supporting students to speak even in bad pronunciation is a wise encouragement. Telling that you (as a teacher) don't care of no matter how they say as long as they can reveal their idea, you'll be happy.
Furthermore, teacher can also encourage their students by giving reward for his/her active students. Teacher don't have to give them an expansive thing, because the existence of this reward is the value of your appreciation.

The next way of encouraging students in learning is urging them to say positive statements for themselves, such as:

I understand a lot more of what is said to me now.

I am a good listener (reader, speaker, writer).

I pay attention well.

I enjoy understanding the new language.

I can get the general meaning without knowing every word.

I'm reading faster than I was a month ago.

People understand me better now.

I had a very successful conversation today.

I can tell my fluency is increasing.

It's ok if I make mistakes.

Everybody makes mistakes; I can learn from mine!

I'm confident and secure about my progress.

(Oxford, 1990)

Moreover, teachers are expected to be, beside of motivator, parent and friend. Parent will listen all problem facing by their children. By asking your students to explore their feelings, that means that you'd help them to lowering their anxiety. As people need to share what they are feeling to express their pique for being better.

\section{Social Strategies and Teachers' Role}

Speaking is a standard model of people communication. People tend to speak instead of interacting using hint or body language. There were research results that female do talk more than male, but it still debatable. Similarly, according to this 
study, female Thai students implement social strategies in higher frequency than others. It indicates that female Thai students tended to acquire new language by communicating with other people. Social strategies deal with social behavior. Language itself is behavior. Implementing social strategies means implementing four language skills in once (listening, speaking, reading and writing).

Social strategies consist of asking question, cooperating with others, and empathizing with others. Based on the study, the female Thai students reported that if they do not understand something in English, they ask the other person to slow down or say it again. This action reflects asking verification and clarification. They also asked teacher and friends to correct them when talk in English. As females had reported in questionnaires that "if I don't understand, I ask the speaker to slow down, repeat, or clarify what was said; I ask other people to verify what I have understood something correctly; I ask other people to correct my pronunciation; I work with other language learners to practice, review and share information; and I pay close attention to the thoughts and feeling of other people with whom I interact in new language."

Asking questions for clarification or verification is more often used by students than asking for correction. This strategy is so simple but it can improve the students' ability in speaking and listening significantly. Teacher can help their students to implement this strategy well by teaching them about appropriate conversational question like the following:

Would you repeat that please?

Please speak more slowly.

I'm sorry, I don't understand.

Pardon me.

What was that again?

Did you say $?$
What does mean?

(Oxford, 1990)

Moreover, females were always making a small group learning almost in everywhere and spending few minutes to speak out, practice and share anything (even their feeling) by using English. That was the best way of improving language proficiency by practice with other students. As teacher, facilitating students with a small group assignment, will help them to finish their assignment by cooperating with peers and practice a variety of language skill naturalistically.

Here are some examples of cooperating with peers. Asking your students to stop competing with their fellow students and learn to work together in learning the new language. Asking them to meet a native speaker visiting from another country and then keep in touch with that person by writing in the new language (Oxford, 1990). Then, find the proficient students in the classroom and spread them into different group to help other students who have lower proficiency.

In addition, by asking students for having friends form English countries and observing their feelings and thoughts will help students to understand English conversation easily. This also helps students know how to respond.

\section{CONCLUSION}

According to the research finding, the males Thai students tended to implement affective strategies, meanwhile female Thai students tended to implement social strategies. Those both strategies call as indirect strategies. Indirect strategies are useful in virtually all language learning situations and are applicable to all four language skills. This strategies support and manage language learning without directly involving with the target language.

The Thai students' tendency on implementation of English language 
learning strategies indirectly reflect their feelings and condition in language learning process. Teachers must be aware of his/her students' conditions.

Teaching students of how to implement six language learning strategies are the best way of helping them to acquire new language. Students must be able to implement, not only, indirect strategies, but also, direct strategies. As direct strategies involve mental process of language learners. Managing language learning is a must, but remembering and retrieving new information, understanding and producing the language are also very important.

In some cases, students are unaware of such actions as being strategies and of the way these strategies would benefit their learning (Ries, 2012). As in language learning process, the different task demands different strategies. The mistakes probably done by students are saying negative statements to themselves, and not checking their understanding of the topic. By teaching language learning strategies, hopefully, will resolve students' problem in learning.

In order to improve the students' learning capacity, proper attention should be given to developing both cognitive and metacognitive aspects (Rinkevičienè \& Zdanytè, 2002), i.e.,

- Personal awareness: self-concept, self-esteem and self-direction;

- Awareness of the learning process: process management;

- Task awareness: knowledge of language and communication.

Teachers' success in promoting the use of learning strategies depends on a number of variables beyond their control. Among these are mandated textbook requirements; high-stakes tests; curricula; class size and configuration; and schedules (Rubin, 2013). Explaining to students of what, why, when and how a strategy can be used and providing examples are the best way of raising the learners' awareness of language learning strategies use.

\section{REFERENCE}

A. Charhil, C. Suarez-Orozco, \& M. Paez. (2008). Explaining English Language Proficiency among Adolescent Immigrant Students. American Education Research Journal, 45(4), 1155-1179.

Anna Kuśnierek. (2016). The Role of Music and Songs in Teaching English Vocabulary to Students. World Scientific News, 43(1), 1-55.

Catharina Aletta Horn. (2007, February). English Second Language Learners: Using Music to Enhance the Listening Abilities of Grade Ones. University of South Africa, Pretoria.

D. Hewitt. (2008). Understanding Effective Learning: Strategies for the Classroom. London: Open University Press.

Daniel Fernando Pérez Niño. (2010). The Role of Music in Young Learners' Oral \{roduction in English. Profile, 12(1), 141-157.

Erin McMullen, \& Jenny R. Saffran. (2004). Music and Language: A Developmental Comparison. Spring, 21(3), 289-311. https://doi. org/10.1525/mp.2004.21.3.289

Ernesto Macaro.(2001). Learning Strategies in Foreign and Second Language Classrooms. New York: Continuum.

Ilona Rinkevičienè, \& Jūratė Zdanytè. (2002). Raising Students' Awareness in Language Learning. Kalbu Studijos, 3. Retrieved from https:// 
www.kalbos.1t/zurnalai/03 numeris/18.pdf

J. O’Malley, \& A. Chamot. (1990). Leraning Strategies in Second Language Acquisition. Cambridge: Cambridge University Press.

Joan Rubin. (2013). Teaching LanguageLearning Strategies. In The Encyclopedia of Applied Linguistics . Blackwell Publishing Ltd. Retrieved from http://www.workingnet.com/ joanrubin/pdfs/wbeal1165.pdf

Liza Lee, \& Chuan Lin. (2015). The Impact of Music Activities on Foreign Language, English Learning for Young Children. Journal of the European Teacher Education Network, 10, 13-23.

Loenice Passarella Dos Ries. (2012). The Importance of Teaching Language Learning Strategies in Additional Language Classes in Brazil. Estudos Anglo-Americanos, 37, 81-108.

Meredith D. Gall, Joyce P. Gall, \& Walter R. Borg. (2003). Educational Research (7th ed.). Boston: Pearson Education Inc.

Oxana Alexandrovna Yarikova. (2009). Influence of Music Lessons on the Vocabulary of Bulingual Children: A Study omong 16 Bilingual Children Living in Mixed Communicative Environment in Olso, Norway. University of Olso, Norway.

Pathomchaiwat, P. (2013). English Language Learning Strategies Used by University Students: A Case Study of English and Business English Major at Suan Sunandha Rajabhat in Bangkok. World Academy of Science, Engineering and Technology, International Journal of Social, Behavioral, Educational, Economic,
Business and Industrial Engineering, 7(5), 1157-1161.

P.M. Lightbrown, \& S. Nina. (2006). How Languages are Learned. Oxford: Oxford University Press.

Rebecca L. Oxford. (1990). Language Learning Strategies: What Every Teacher Should Know. Boston: Heinle \& Heinle.

Rod Ellis. (1999). The Study of Second Language Acquisition. New York: Oxford University Press.

Sri Wahyuni, \& Muhammad Ilyas. (2016). An Investigation of Thai Students' English Language Problems and Their Learning Strategies at English Study Program of Teacher Training and Education Faculty of Riau Islamic University. $J$-SHMIC, 3(2), 81-91.

Srisupha, R. (2013). Thai Students' Language Learning Strategies. Quarterly Journal of Chinese Studies, 2(2), 53.

Suwanarak, K. (2015). Learning English as Thai Adult Learners: An Insight into Experience in Using Learning Strategies. English Language Teaching, 8(12), 144-157. 